\title{
SRSF3 Gene
}

National Cancer Institute

\section{Source}

National Cancer Institute. SRSF3 Gene. NCI Thesaurus. Code C97785.

This gene plays a role in RNA splicing and export. 